\title{
The Journal of Pediatric Academy is Launching
}

\begin{tabular}{|c|c|c|}
\hline Author(s) & \multicolumn{2}{|l|}{ (D) Duran Arslan } \\
\hline Affiliation(s) & \multicolumn{2}{|c|}{${ }^{1}$ Department of Pediatrics, Erciyes University, Faculty of Medicine, Kayseri, Turkey } \\
\hline \multirow{3}{*}{$\begin{array}{c}\text { Article } \\
\text { Information }\end{array}$} & Article Type: Editorial & Received: 12.06 .2020 \\
\hline & Article Group: General Pediatrics & Accepted: 12.06 .2020 \\
\hline & & Available Online: 31.07 .2020 \\
\hline
\end{tabular}

\section{Editorial Comment}

Dear Colleagues,

Erciyes University Faculty of Medicine, Department of Pediatrics has been serving with great enthusiasm and success to protect Child Health and treat pediatric diseases in our country for half a century. We are proud to have raised a great number of pediatricians and subspecialists serving as physicians, physician-scientists and academics all over our country and across the globe.

We proudly present our newly established journal, The Journal of Pediatric Academy (JPA). We would like to share our scientific experiences with the national and international medical experts through JPA. Our aim is to be a permanent publication indexed in National and International indexes without sacrificing the quality, ethical and scientific principles.

The Journal of Pediatric Academy aims to be publish novel articles in general pediatrics and pediatric subspecialties (Emergency Medicine, Allergy and Immunology,
Endocrinology, Gastroenterology, Hepatology and Nutrition, Genetics, Cardiology, Hematology-Oncology, Infectious Diseases, Metabolism, Nephrology, Neurology, Rheumatology, Pulmonology, Social Pediatrics, Newborn, Critical Care Medicine, Ethics and Health Service Research), as well as relevant specialties such as Pediatric Surgery, Child and Adolescent Psychiatry, Pedodontics, Pediatric Nursing and Family Physicians.

We are aware that we started our publishing life during these difficult times due to COVID 19 pandemic. However, having a highly motivated and diligent team in the kitchen of the magazine helped us overcome these difficulties.

In our first issue, we come before you with articles of great importance and original topics and case reports in pediatrics field.

Dr. Çiçek \& Kısaarslan ${ }^{1}$ reviewed the clinical guidelines for rheumatic COVID-19 children in their review article.

Correspondence: Duran Arslan, Erciyes University, Faculty of Medicine, Department of Pediatrics, 38080, Melikgazi, Kayseri, Turkey

E-mail: duranarslan63@gmail.com 
In this issue Kurtoğlu et $\mathrm{al}^{2}$ reported the first study that show body mass index (BMI), fat mass (FM), fat free mass (FFM), and body fat \% in Turkish children and adolescents. Their study sample has consisted of more than 4000 children and adolescent. The result of this study can be regarded as a base the final product of the data of Determination of Anthropometric Measures of Turkish Children and Adolescents (DAMTCA II) study. Beside reference values, they also checked the age specific contribution of fat mass index (FMI), fat free mass index (FFMI) to $\mathrm{BMI}$ and fat \% with Hattori chart. Both in screening and clinical practice use of FMI and FFMI together with BMI would significantly contribute to detection and follow-up of adiposity rebound, puberty precious, delayed puberty, overweight and obesity.

Dr. Yel et $\mathrm{al}^{3}$ determined the etiological reasons and frequency of prenatal determined hydronephrosis and evaluated the renal functions in 48 patients.

Dr. Çıraklı et $\mathrm{al}^{4}$ reported the clinical and electrophysiological features, treatment, and outcome of 15 children with hot water epilepsy.

Dr. Vatansever et $\mathrm{al}^{5}$ reported their experience of 126 critically ill children with hyperglycemia in pediatric intensive care unit. The effect of thiamine pyrophosphate level on mortality and morbidity in patients with hyperglycemia at the time of application was evaluated.

In addition, two interesting case reports by Dr. Kara ${ }^{6}$, Dr. Aydın ${ }^{7}$ were also included in the first issue of the JPA.
We wish best of luck to JPA family and looking forward to the valuable contributions of our colleagues in the coming period.

\section{References}

1. Özdemir Çiçek S, Paç Kısaarslan A. Pediatric rheumatologists' perspective on corona virus disease 19 J Pediatr Acad 2020; 1(1): 3-7.

2. Kurtoğlu S, Mazıcıoğlu MM, Öztürk A, Hatipoğlu N, Çiçek B, Zararsız G. Fat and fat free mass index reference percentiles of healthy Turkish children and adolescent in Turkey. J Pediatr Acad 2020; 1(1): 8-15.

3. Yel S, Poyrazoğlu H. One-year follow-up results of patients with prenatally diagnosed hydronephrosis and evaluation of renal functions. J Pediatr Acad 2020; 1(1): 16-20.

4. Çıraklı S, Kaçar Bayram A, Akdemir A, Canpolat M, Kumandaş $S$, Gümüş $H$, Per H. Clinical and EEG features, treatment, and outcome of hot water epilepsy in pediatric patients. J Pediatr Acad 2020; 1(1): 21-24.

5. Vatansever Z, Özsoylu S, Kendirci M, Akyıldız B. The effect of thiaminepyrophosphate levels on mortality and morbidity in patients with stress hyperglycemia. J Pediatr Acad 2020; 1(1): 2529.

6. Kara B, Kartal A, Öztürk M, Köksal Y. Wernicke Encephalopathy Due to Prolonged Total Parenteral Nutrition in A Child with Signet Ring Cell Gastric Carcinoma. J Pediatr Acad 2020; 1(1): 30-33.

7. Aydın F, Altay D, Görükmez O, Hafo Kiraz A, Karaman F, Özcan A, Yılmaz E, Kurtsoy, A, Özkan KU, Deniz K, Per H, Karakukcu M, Ünal E, Patıroğlu T. Glioblastoma and Colorectal Adenocarcinoma in an Adolescent Girl with Constitutional Mismatch Repair Deficiency syndrome mimicking Neurofibromatosis Type-I. J Pediatr Acad 2020; 1(1): 34-38. 